UDC: $636.32 / 38: 677.31: 577.1$

\title{
OBTAINING HUMAN HAIR KERATIN-BASED FILMS AND THEIR CHARACTERISTICS
}

\author{
V. V. Mykhaliuk 1*, V. V. Havryliak (i) 2 \\ ${ }^{1}$ Institute of Animal Biology, NAAS of Ukraine, 38 V. Stus St., Lviv 79034, Ukraine \\ ${ }^{2}$ Lviv Polytechnic National University, Institute of Chemistry and Chemical Technologies \\ 3/4 Sviatoho Yura Sq., Lviv 79013, Ukraine \\ *Corresponding author e-mail: vasylyna.v.m@gmail.com
}

Mykhaliuk V.V., Havryliak V.V. Obtaining human hair keratin-based films and their characteristics. Studia Biologica, 2021; 15(1): 27-36 • DOI: https://doi.org/10.30970/sbi.1501.643

Background. Keratins are natural biopolymers with a wide range of applications in the field of biotechnology.

Materials and Methods. Extraction of keratins was performed by a modified Nakamura method using $250 \mathrm{mM}$ DTT. The protein concentration in the supernatant was determined by Bradford method. The protein composition was studied by their electrophoretic separation in a polyacrylamide gel in the presence of sodium dodecyl sulfate. The films were made by casting. The surface characteristics of the films were determined using a scanning electron microscope REMMA-102. The elemental composition of the films was determined using an X-ray microanalyzer.

Results. The protein concentration in the supernatant was $3.75 \mathrm{mg} / \mathrm{mL}$. After using dithiothreitol in the extraction mixture, we obtained proteins of intermediate filaments with a molecular weight of 40-60 kDa and a low Sulfur content. In the low molecular weight region, we obtained keratin-associated proteins with a molecular weight of 10 $30 \mathrm{kDa}$ and a high content of Sulfur. These proteins belong to fibrillar proteins, which can be used as a matrix for the creation of new keratin-containing biocomposites with a wide range of applications in reparative medicine and tissue engineering.

Based on the obtained keratin extract, polymer films with and without the addition of glycerol were made. Scanning electron microscopy revealed that glycerol provided the film structure with homogeneity and plasticity due to the accumulation of moisture after the fixation by water vapor.

The X-ray microanalysis of films revealed such elements as Sodium, Silicon, Sulfur, Potassium. Among the detected elements, Sulfur has the largest share that is due to the large number of disulfide bonds in the keratin molecule.

(C) 2021 V. V. Mykhaliuk et al.; Published by the Ivan Franko National University of Lviv on behalf of Біологічні Студії / Studia Biologica. This is an Open Access article distributed under the terms of the Creative Commons Attribution License (http://www.budapestopenaccessinitiative.org and Creative Commons Attribution 4.0 License), which permits unrestricted reuse, distribution, and reproduction in any medium, provided the original work is properly cited.

ISSN 1996-4536 (print) • ISSN 2311-0783 (on-line) • Біологічні Студії / Studia Biologica • 2021 • Том 15 / № 1 • С. 27-36 
Conclusions. The polymer keratin films with the addition of glycerol demonstrated better mechanical properties and can be used in biomedicine.

Keywords: keratins, hair, extraction, biopolymers

\section{INTRODUCTION}

The number of studies of protein-containing compounds such as gelatin, collagen, albumin, silk fibroin and keratin for their use in biomedicine and engineering is constantly growing. This is due to the significant demand for natural and renewable materials, the production of which would be environmentally friendly and cost-effective [1, 3 , $5,18]$. Keratins are a potential raw material for the creation of biomaterials due to their biodegradability, self-assembly ability and low cytotoxicity [8].

One of the promising ways of the creation of biomaterials is the production of keratin films used in biomedicine $[4,7,11]$, in particular as a substrate for cell cultivation. In this regard, keratins have successfully demonstrated the possibility of replacing polystyrene previously used for the manufacture of materials of this type [12]. According to literature, pre-treatment of substrates with keratins stimulates cell adhesion and proliferation. It has been shown that keratin films are used in particular for culturing mouse L929 fibroblasts [12].

Yamauchi et al. studied the physicochemical properties and biodegradation ability of keratin films [21]. According to their research, the combination of extracted keratin with glycerol promotes their biodegradability, makes the films transparent, strong and more flexible [21], and the combination with chitosan also gives them antibacterial properties $[17,20]$.

Tonin et al. [19] demonstrated the prospects for combining keratin films with a synthetic polymer such as polyethylene oxide. The films of this type can be used not only as a framework for cell growth, but also as a membrane for drug delivery. For this purpose, keratins were combined with hydrotalcite nanoparticles containing diclofenac [14]. Such hybrid films, compared to those containing unbound diclofenac, were characterized by a lesser degree of porosity and swelling, but were more heat-resistant and released diclofenac better under physiological conditions than non-hybrid ones.

Based on literature analysis, one can conclude that natural polymers, in particular keratins, are a promising biomaterial with ta possibility of application in biomedicine and bioengineering.

\section{MATERIALS AND METHODS}

Only samples of pigmented hair, which had not previously been dyed with either natural or synthetic dyes were used. All hair samples were provided by healthy females aged 20 to 25 years with their written consent. The research was conducted in accordance with the decision of the Commission of bioethical examination of the Institute of Animal Biology of NAAS of 16.06.2020, protocol No. 83, which meets the requirements of bioethical examination according to the Order of the Ministry of Health of Ukraine No. 281 of 01.11 .2000 , European Convention for the protection of vertebrate animals used for experimental and other scientific purposes of 18.03.1986 and the EEC Directive No. 609 of 24.11 .1986 . The experiments were conducted in the laboratory of metabolism named after Stepan Gzhytskyi.

ISSN 1996-4536 (print) • ISSN 2311-0783 (on-line) • Біологічні Студії / Studia Biologica • 2021 • Том 15 / № 1 • C. 27-36 
The keratin extract obtained from human hair was used for the production of films. Hair samples weighing $0.5 \mathrm{~g}$ each were ground, washed in $1 \%$ sodium dodecyl sulfate (SDS) solution, rinsed with distilled water and dried at room temperature. For keratin extraction, we modified the method proposed by Nakamura [13] using dithiothreitol of the same concentration instead of 2-mercaptoethanol. Protein solubilization was performed in an extraction mixture consisting of $25 \mathrm{mM}$ Tris- $\mathrm{HCl}, 5 \mathrm{M}$ urea, $2.6 \mathrm{M}$ thiourea and $250 \mathrm{mM}$ dithiothreitol. Each hair sample was placed in $25 \mathrm{~mL}$ of the extraction mixture. Protein extraction was performed at a temperature of $60^{\circ} \mathrm{C}$ at $\mathrm{pH} 8.5$ for 72 hours. During this time, the samples were stirred several times with a glass rod for better contact of hair with the extraction mixture. The obtained extraction mixture was filtered and dialyzed against distilled water. The protein concentration in the solution was determined by colorimetric method using Bradford's reagent.

To determine the composition of the extracted proteins, we used PAGE in the Lemmly buffer system with the addition of SDS.

After electrophoresis, the gels were stained with a $0.2 \%$ solution of Coomassie $\mathrm{R}-250$, and then washed with a $7 \%$ solution of acetic acid in distilled water.

Two types of films were prepared from the obtained proteins. The first type was a keratin-glycerol film prepared from a $4 \%$ solution of keratin in distilled water with the addition of $1 \%$ glycerol. The film of the second type consisted of only $4 \%$ aqueous solution of keratin. Suitable solutions were poured into Petri dishes in a thin layer that did not exceed $3.0 \mathrm{~mm}$, and incubated in a thermostat for $24 \mathrm{~h}$ at $37^{\circ} \mathrm{C}$. After that, the films were fixed for $24 \mathrm{~h}$ in room temperature water vapor in a desiccator.

The features of the films surface were examined using a scanning electron microscope REMMA-102. The elemental composition of the films was determined using an X-ray microanalyzer.

\section{RESULTS AND DISCUSSION}

Keratins extracted from wool and human hair in aqueous solutions have the ability to self-assemble, forming the films [16], which has been used to study the structure and functions of self-organized keratins. Keratin-based films are successfully used in tissue engineering because they have the ability to support and improve cell growth, adhesion, migration and proliferation $[3,4,12,16]$, as well as for controlled drug delivery $[13,16,18]$.

Keratin-only films are very brittle and fragile [23]. Literature describes many ways of solving this problem [6, 9, 22]. In our experiments, we used glycerol to provide the films with elasticity. In addition, glycerol can be washed out of the film with aqueous solutions, if necessary [16]. Glycerol reduces intramolecular and intermolecular forces, thus improving the flexibility of the polymer. According to the studies of the effect of different concentrations of glycerol on the physical properties of keratin films, it was found that the use of this plasticizer in the amount of $0.09 \mathrm{~g} / \mathrm{g}$ increases the tensile strength of the film by about 15 times [12], and has the greatest impact on moisture retention [10].

As a result of extraction of keratins using DTT as a reducing agent, we obtained a protein solution at a concentration of $3.75 \mathrm{mg} / \mathrm{mL}$. DTT is used due to its ability to effectively restore disulfide bonds. As a result of such extraction keratins that retain the properties of native keratin are formed. It is very important for the production of biomaterials.

ISSN 1996-4536 (print) • ISSN 2311-0783 (on-line) • Біологічні Студії / Studia Biologica • 2021 • Том 15 / № 1 • C. 27-36 
In Fig. 1, the electrophoretic profile of human hair keratins is characterized by the presence of two polypeptide chains with a molecular weight in the range of $40-50 \mathrm{kDa}$, which correspond to type I and type II proteins of intermediate filaments (IF) with low Sulfur content.

In the low molecular weight region, bands of proteins with a molecular mass of 10-30 kDa were detected, which are sulfur-rich keratin-associated proteins (KAP).



After the composition of the extracted keratins had been studied, the obtained protein solutions were used for the production of polymer films. Depending on the purpose of production of polymeric films they can be combined with both synthetic and natural materials. In the research, we used glycerol as a safe and cheap plasticizer. We also made a polymer film without the addition of plasticizer for comparison. Fig. 2 shows keratin films after incubation in a thermostat at the temperature of $37^{\circ} \mathrm{C}$.
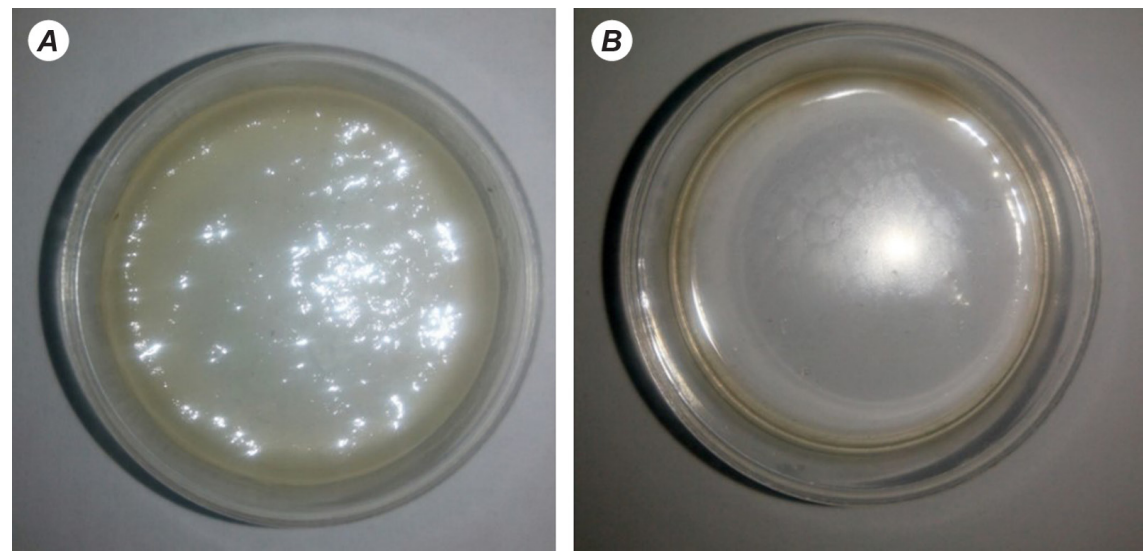

Fig. 2. The film based on $4 \%$ keratin solution with addition of $1 \%$ glycerol $(\boldsymbol{A})$; the film without glycerol addition $(B)$

Рис. 2. Плівка на основі 4\% розчину кератину з додаванням $1 \%$ гліцеролу $(\boldsymbol{A})$; плівка без додавання гліцеролу (B)

ISSN 1996-4536 (print) • ISSN 2311-0783 (on-line) • Біологічні Студії / Studia Biologica • 2021 • Том 15 / № 1 • С. 27-36 
The method of stabilizing keratins extracted from human hair with water vapor was tested for the first time. As can be seen from Fig. 2, the film based on keratin and glycerol $(\boldsymbol{A})$ acquired a gel-like consistency after stabilization in water vapor, which is explained by the property of glycerol to accumulate moisture, as mentioned above. At that time, the film made only from an aqueous solution of keratin $(\boldsymbol{B})$ was represented by a thin polymer layer, which was easily torn when trying to separate it from the Petri dish, which was not typical of keratin-glycerol film. This confirms that glycerol improves mechanical properties of the film.

In Fig. 3, scanning electron microscopy shows the surface of the film made by combining a $4 \%$ aqueous solution of keratin with the addition of $1 \%$ glycerol $(\boldsymbol{A})$ and the surface of the film made without the addition of glycerol $(\boldsymbol{B})$. As can be seen from Fig. $3 A$, the surface of the film is mostly homogeneous, without cavities and holes, with a small number of built-in granules of different shapes. The presence of single cracks may be due to a large number of intermolecular bonds [2].
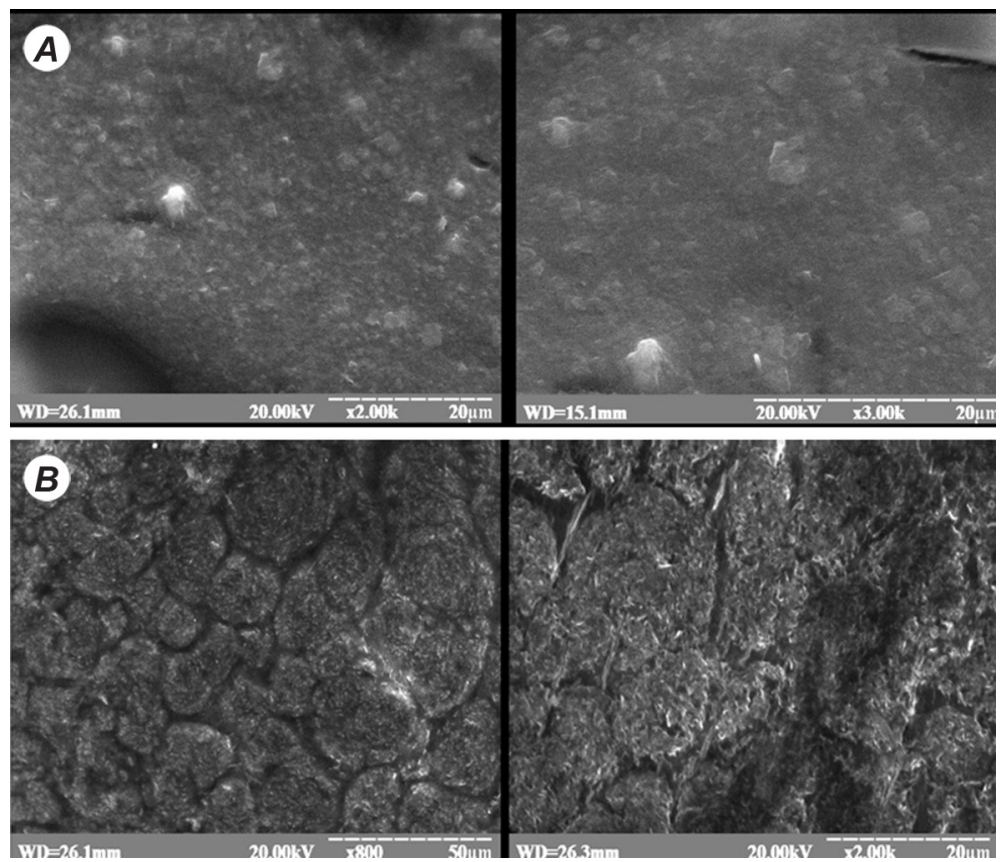

Fig. 3. Scanning electron microscopy of the film made of $4 \%$ keratin solution with addition of $1 \%$ glycerol $(\boldsymbol{A})$ and the film without glycerol addition $(\boldsymbol{B})$

Рис. 3. Сканувальна електронна мікроскопія плівки, виготовленої з $4 \%$ розчину кератину з додаванням $1 \%$ гліцеролу $(\boldsymbol{A})$ і плівки без додавання гліцеролу $(\boldsymbol{B})$

The surface the film without glycerol is not homogeneous and has a large number of recesses and protrusions (Fig. 3B).

Fig. 4 shows the chemical composition of the film made of $4 \%$ reduced keratin solution with the addition of $1 \%$ glycerol $(\boldsymbol{A})$ and without glycerol $(\boldsymbol{B})$. Qualitative analysis revealed that differences between both types of film are nearly indistinguishable. We detected such elements as Sodium, Silicon, Sulfur, Potassium. Among the studied elements, Sulfur has the largest share, while the other elements have much lower shares. 


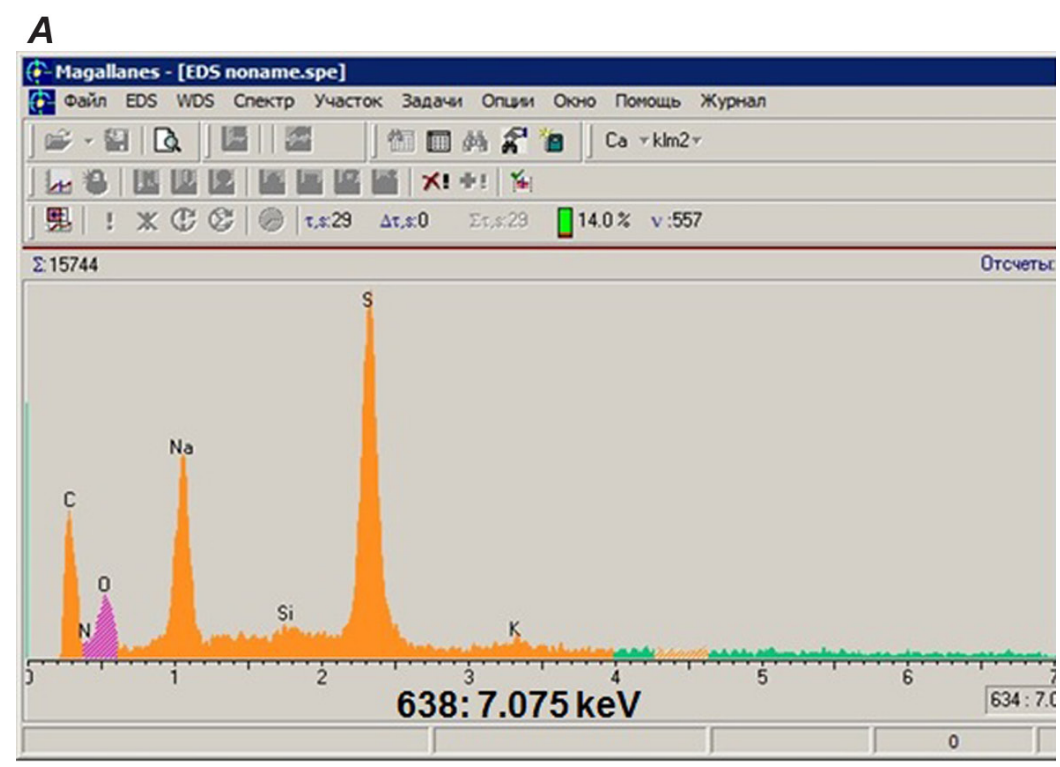

B

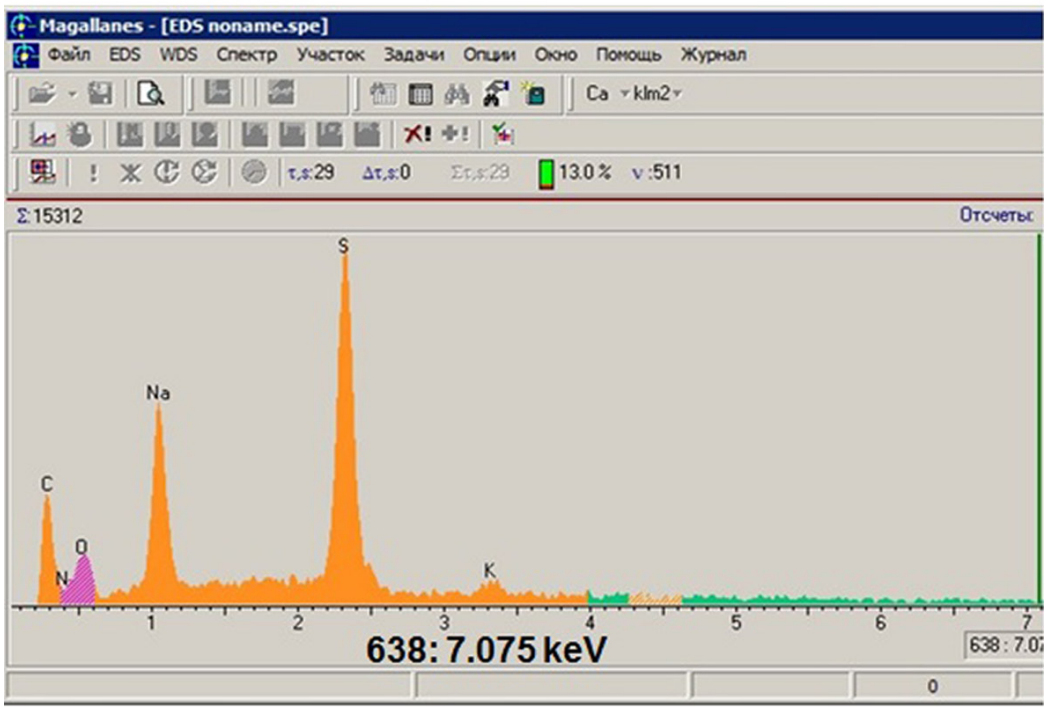

Fig. 4. X-ray microanalysis spectra of the film made with $4 \%$ keratin solution with the addition of $1 \%$ glycerol $(A)$ and the film made of $4 \%$ keratin solution alone $(B)$

Рис. 4. Спектри рентгенівського мікроаналізу плівки, виготовленої з 4\% розчину кератину з додаванням $1 \%$ гліцеролу $(\boldsymbol{A})$ та плівки, виготовленої тільки з 4\% розчину кератину $(\boldsymbol{B})$

High Sulfur content is caused by the presence of a large number of disulfide bonds in the keratin molecule, mainly due to cysteine residues.

Apart from Sulfur, another important element is Silicon that provides hardness to keratinized tissues and promotes their high chemical resistance.

The Table shows the content of elements of both types of films. 
The content of chemical elements in the films, \%

Вміст хімічних елементів у плівках, \%

\begin{tabular}{l|c|c}
\hline \multicolumn{1}{|c}{ Element } & $\begin{array}{c}\text { The film made with } 4 \% \text { keratin solution } \\
\text { with the addition of } 1 \% \text { glycerol }\end{array}$ & $\begin{array}{c}\text { The film made of } 4 \% \text { keratin } \\
\text { solution alone }\end{array}$ \\
\hline Sulfur & 12.89 & 12.76 \\
Sodium & 3.11 & 3.12 \\
Silicon & 0.21 & - \\
\hline Potassium & 0.38 & 0.65 \\
\hline
\end{tabular}

This elemental composition is characteristic of the regenerated keratin.

\section{CONCLUSIONS}

1. Protein extraction was performed using a modified method of Nakamura using DTT as a reductant in the extraction mixture. The chosen method of solubilization of keratins allows for obtaining IF proteins of type I and II with a molecular weight of 60-70 kDa and low molecular weight KAP with a molecular weight of 10-30 kDa. The fibrillar structure of these proteins makes them a potential raw material for the production of biomaterials.

2. The polymer film made on the basis of protein extract with the addition of glycerol demonstrated better mechanical properties and homogeneous structure, in contrast to the film made without the addition of glycerol. Improved mechanical properties of the film facilitate their application. In addition, the safety of glycerol, which we used as a plasticizer, allows for the use of keratin films in biomedicine.

3. The method of stabilization of films made on the basis of keratins of human hair with the help of water vapor was tested.

4. The results of X-ray microanalysis of films indicate a high presence of Sulfur. Apart from Sulfur, such elements as Potassium, Sodium and Silicon were detected, which is characteristic of the elemental composition of the regenerated keratin.

\section{COMPLIANCE WITH ETHICAL STANDARDS}

Human Rights: All procedures performed in studies involving human participants were in accordance with the ethical standards of the institutional and/or national research committee and with the 1964 Helsinki declaration and its later amendments or comparable ethical standards

1. Aigner T.B., DeSimone E., Scheibel T. Biomedical applications of recombinant silk-based materials. Advanced Materials, 2018; 30(19): 1704636.

Crossref $\bullet$ PubMed $\bullet$ Google Scholar

2. Alashwal B.Y., Saad Bala M., Gupta A., Sharma S., Mishra P. Improved properties of keratinbased bioplastic film blended with microcrystalline cellulose: A comparative analysis. Journal of King Saud University - Science, 2020; 32(1): 853-857.

Crossref $\bullet$ Google Scholar

3. Bhardwaj N., Sow W.T., Devi D., Ng K.W., Mandal B.B., Cho N.J. Silk fibroin-keratin based 3D scaffolds as a dermal substitute for skin tissue engineering. Integrative Biology, 2015; 7(1): 53-63.

Crossref $\bullet$ PubMed $\bullet$ Google Scholar 
4. Cochis A., Ferraris S., Sorrentino R., Azzimonti B., Novara C., Geobaldo F., Rimondini L. Silver-doped keratin nanofibers preserve a titanium surface from biofilm contamination and favor soft-tissue healing. Journal of Materials Chemistry B, 2017; 5(42): 83668377.

Crossref $\bullet$ PubMed $\bullet$ Google Scholar

5. Costa F., Silva R., Boccaccini A.R. Fibrous protein-based biomaterials (silk, keratin, elastin, and resilin proteins) for tissue regeneration and repair. Peptides and Proteins as Biomaterials for Tissue Regeneration and Repair, 2018; 175-204. Crossref $\bullet$ Google Scholar

6. Feng Y., Borrelli M., Meyer-Ter-Vehn T., Reichl S., Schrader S., Geerling G. Epithelial wound healing on keratin film, amniotic membrane and polystyrene in vitro. Current Eye Research, 2014; 39(6): 561-570.

Crossref $\bullet$ PubMed $\bullet$ Google Scholar

7. Feroz S., Muhammad N., Ranayake J., Dias G. Keratin - Based materials for biomedical applications. Bioactive Materials, 2020; 5(3): 496-509.

Crossref • PubMed • PMC • Google Scholar

8. Gupta P., Nayak K.K. Characteristics of protein-based biopolymer and its application. Polymer Engineering \& Science, 2015; 55(3): 485-498.

Crossref $\bullet$ Google Scholar

9. Kavitha A., Boopalan K., Radhakrishnan G., Sankaran S., Das B.N., Sastry T.P. Preparation of feather keratin hydrolyzate-gelatin composites and their graft copolymers. Journal of Macromolecular Science, Part A, 2005; 42(12): 1703-1713.

Crossref $\bullet$ Google Scholar

10. Martelli S.M., Moore G., Paes S.S., Gandolfo C., Laurindo J.B. Influence of plasticizers on the water sorption isotherms and water vapor permeability of chicken feather keratin films. LWT Food Science and Technology, 2006; 39(3): 292-301.

Crossref $\bullet$ Google Scholar

11. McLellan J., Thornhill S.G., Shelton S., Kumar M. Keratin-Based Biofilms, Hydrogels, and Biofibers. In: Sharma S., Kumar A. (eds) Keratin as a Protein Biopolymer. Springer Series on Polymer and Composite Materials. Springer, Cham., 2019; 187-200.

Crossref $\bullet$ Google Scholar

12. Moore G.R.P., Martelli S.M., Gandolfo C., Sobral P.J.A., Laurindo J.B. Influence of the glycerol concentration on some physical properties of feather keratin films. Food Hydrocolloids, 2006; 20(7): 975-982.

Crossref $\bullet$ Google Scholar

13. Nakamura A., Arimoto M., Takeuchi K., Fujii T. A rapid extraction procedure of human hair proteins and identification of phosphorylated species. Biological and Pharmaceutical Bulletin, 2002; 25(5): 569-572.

Crossref $\bullet$ PubMed $\bullet$ Google Scholar

14. Posati T., Giuri D., Nocchetti M., Sagnella A., Gariboldi M., Ferroni C., Aluigi A. Keratinhydrotalcites hybrid films for drug delivery applications. European Polymer Journal, 2018; 105: 177-185.

Crossref $\bullet$ Google Scholar

15. Reichl S. Films based on human hair keratin as substrates for cell culture and tissue engineering. Biomaterials, 2009; 30(36): 6854-6866.

Crossref $\bullet$ PubMed $\bullet$ Google Scholar

16. Shavandi A., Silva T.H., Bekhit A.A., Bekhit A.E.-D.A. Keratin: dissolution, extraction and biomedical application. Biomaterials Science, 2017; 5(9): 1699-1735.

Crossref $\bullet$ PubMed $\bullet$ Google Scholar

17. Tanabe T., Okitsu N., Tachibana A., Yamauchi K. Preparation and characterization of keratinchitosan composite film. Biomaterials, 2002; 23(3): 817-825.

Crossref • Google Scholar

ISSN 1996-4536 (print) • ISSN 2311-0783 (on-line) • Біологічні Студії / Studia Biologica • 2021 • Том 15 / № 1 • C. 27-36 
18. Thonpho A., Srihanam P. Preparation and characterization of keratin blended films using biopolymers for drug controlled release application. Oriental Journal of Chemistry, 2016; 32(4): 1739-1748.

Crossref $\bullet$ Google Scholar

19. Tonin C., Aluigi A., Vineis C., Varesano A., Montarsolo A., Ferrero F. Thermal and structural characterization of poly(ethylene-oxide)/keratin blend films. Journal of Thermal Analysis and Calorimetry, 2007; 89: 601-608.

Crossref $\bullet$ Google Scholar

20. Vaz J.M., Pezzoli D., Chevallier P., Campelo C.S., Candiani G., Mantovani D. Antibacterial coatings based on chitosan for pharmaceutical and biomedical applications. Current pharmaceutical design, 2018; 24(8): 866-885.

Crossref $\bullet$ PubMed $\bullet$ Google Scholar

21. Yamauchi K., Yamauchi A., Kusunoki T., Kohda A., Konishi Y. Preparation of stable aqueous solution of keratins, and physiochemical and biodegradational properties of films. Journal of Biomedical Materials Research,1996; 31: 439-444.

Crossref $\bullet$ Google Scholar

22. Yin X.-C., Li F.-Y., He Y.-F., Wang Y., Wang R.-M. Study on effective extraction of chicken feather keratins and their films for controlling drug release. Biomaterials Science, 2013; 1(5): 528.

Crossref $\bullet$ PubMed $\bullet$ Google Scholar

23. Zhuang Y., Wu X., Cao Z., Zhao X., Zhou M., Gao P. Preparation and characterization of sponge film made from feathers. Materials Science and Engineering: C, 2013; 33(8): 4732-4738.

Crossref $\bullet$ PubMed $\bullet$ Google Scholar

\title{
ОТРИМАННЯ ТА ХАРАКТЕРИСТИКА ПЛІВОК НА ОСНОВІ КЕРАТИНІВ ВОЛОССЯ ЛЮДИНИ
}

\author{
В. В. Михалюк ${ }^{1 *}$ В. В. Гавриляк ${ }^{2}$ \\ ${ }^{1}$ Інститут біології тварин НААН, вул. В. Стуса, 38, Львів 79034, Україна \\ ${ }^{2}$ Національний університет "Львівська політехніка", \\ Інститут хімії та хімічних технологій, пл. Св. Юра, 3/4, Львів 79013, Україна \\ *Кореспондуючий автор e-mail: vasylyna.v.m@gmail.com
}

Вступ. Кератини - природні біополімери із широким спектром застосування у сорері біотехнологій.

Матеріали та методи. Екстракцію кератинів проводили модифікованим методом Накамура за використання 250 мМ ДТТ. Концентрацію протеїну в супернатанті визначали методом Бредфорда. Дослідження протеїнового складу кератину проводили за допомогою електрофорезу за використання додецилсульфату натрію. Плівки виготовляли методом кастингу. Особливості поверхні плівок визначали за допомогою растрового електронного мікроскопа РЕММА-102. Елементний склад плівок визначали за допомогою рентгенівського мікроаналізатора.

Результати. Концентрація протеїнів, екстрагованих з волоса людини за використання ДТТ, становила 3,75 мкг/мл. Після використання ДТТ у складі екстракційної суміші ми отримали протеїни інтермедіальних фріламентів з молекулярною масою 40-60 кДа та низьким вмістом Сульфуру. В низькомолекулярній ділянці нами виявлено кератин-асоційовані протеїни з молекулярною масою 10-30 кДа і високим 
вмістом Сульфуру. Ці протеїни належать до фрібрилярних протеїнів, які можуть бути матрицею для створення нових кератиновмісних біокомпозитів з широким спектром застосування в регенеративній медицині та тканинній інженерії.

На основі екстрагованих кератинів ми створили плівки з додаванням гліцеролу та без нього. Згідно з результатами сканувальної електронної мікроскопії додавання гліцеролу забезпечувало пластичність і гомогенність плівки внаслідок акумуляції вологи після фріксації у парах води.

Унаслідок рентгенівського мікроаналізу плівок виявлено такі елементи, як Натрій, Силіцій, Сульфур, Калій. Серед усіх виявлених елементів найбільша частка припадає на Сульфур, що пов'язано з великою кількістю дисульфідних зв'язків у молекулі кератину.

Висновки. Полімерні кератинові плівки з додаванням гліцеролу мали кращі механічні властивості й можуть бути застосовані у біомедицині.

Ключові слова: кератини, волос, екстракція, біополімери 